\title{
First Scientific Record for Sivas Aquatic Systems Related to Alien Fish Species:Small-scaled Pacu; Piaractus mesopotamicus (Teleostei:Characidae)
}

\author{
Bülent Ünver ${ }^{1, a, *}$, Durdu Akdağ ${ }^{2, b}$, Saniye Müzeyyen Vicdanlı, ${ }^{2, c}$ \\ ${ }^{1}$ Science Faculty, Sivas Cumhuriyet University, 58140 Sivas, Turkey \\ ${ }^{2}$ Sivas Directorate of Provincial Agriculture and Forestry, 58070 Sivas, Turkey
}

*Corresponding author

\section{A R T I C L E I F O A B S T R A C T}

Research Article

In July 2017, three specimens of an alien fish species were caught by the amateur fishermen in Kizılırmak River at Sivas city center. One of the fish specimens was taken from the fishermen for ichthyologic examination. The morphological, metric (23 features) and meristic characters (13 features) of this specimen were determined. The alien fish is with ovoid shape and flattened

Received : 09/04/2021

Accepted : 14/04/2021 laterally. Mouth is in a sub-ventral position. The tooth row is double. Teeth formula are 3,2 / 2,3 (at first row on maxil) and 2 / 2 (at second row on maxil), 3,3 / 3,4 (at first row on mandibul), 1,1 (at second row on mandibul). The number of rakers on the first gill arch is 33 . The scale numbers in line lateral are 107 (on right side) and 103 (on left side). The number of branched rays of dorsal, anal, pectoral, and ventral fins are 14, 24, 14, and 7; respectively. As a result of the evaluation of morphological, metric and meristic characters, it was decided that the alien fish caught from

Keywords:

Alien species

Translocation

Pacu

Upper Kizilırmak Basin Sivas
Kizllırmak was Piaractus mesopotamicus (Holmberg, 1887) belonging to the Characidae family. This species is also called as the small-scaled pacu. P. mesopotamicus is not among to native fish fauna of Kizilırmak. It is a fish species which originated from South America and is a tropical freshwater fish. These alien fish specimens which were caught by the amateur fishermen, probably translocated from a hobbyist aquarium to this aquatic system. Both directly and indirectly, invasive fishes affect a wide range of native organisms from zooplankton to mammals across multiple levels of biological organizations ranging from the genome to the ecosystem. This study is the first scientific record for Sivas aquatic systems related to alien fish species.

\section{Introduction}

Under the Convention on Biological Diversity, invasive alien species (IAS) are defined as "species whose introduction and/or spread outside their natural past or present distribution threatens biological diversity", encompassing a vast, and rapidly increasing range of nonnative terrestrial, freshwater and marine vertebrates, invertebrates, plants and disease organisms (Genovesi et al., 2015). Invasive alien species are acknowledged as the 3rd cause of biodiversity loss worldwide Convention on Biological Diversity (Anonymous, 2016; Heubach, 2016).

Invasive alien species have invaded and affected native biota in almost every ecosystem type on earth, and have affected all major taxonomic groups. They can lead to the extinction of native species, degradation of ecosystems, declining agricultural productivity and loss of genetic diversity, and damage to property, infrastructure, native fisheries, tourism and outdoor recreation (Genovesi et al., 2015; Heubach, 2016).

IAS, i.e. non-native species that have negative impacts on native ecosystems and biodiversity, have been recognized as one of the currently most serious and expanding threats to biodiversity and ecosystem service and, thus, also to human health and wellbeing. In the perspective of some countries, the negative consequences of invasive alien species on their natural ecosystems even paramount the threat of climate change (Genovesi et al., 2015; Heubach, 2016).

Many exotic species often appear in natural waters where these fish were unknown before. Introductions could be the result of accidents such as the careless release of live specimens from home aquaria, dumping unused baitfish or escapes from nearby aquaculture facilities. Other causes of 
exotic introductions include the negligent transfer of fertilized eggs of unknown species during stocking, opening connective channels with introduced fish to native habitats or simply undocumented stocking (Cowx, 1998; Innal and Erk'akan, 2006).

The impact of introduced species is a neglected, worldwide ecological problem, especially in freshwater systems. Freshwater fish fauna is highly differentiated and isolated, particularly compared to marine fish. For this reason the introduction of freshwater fish, which is common worldwide mainly for aquaculture and angling related purposes, is especially harmful in terms of biodiversity. Exotic and translocated fish species have become established in various parts of the inland waters of Turkey since the 1950s (Innal and Erk'akan, 2006). The abundance of introduced fish has increased in recent years and the diversity of freshwater species has changed in Turkey (Innal and Erk'akan, 2006; Innal, 2012).

Aquatic species have been introduced for several reasons, namely to establish fisheries (commercial and sport) and for aquaculture, as forage for other important species, control of unwanted organisms (aquatic vegetation, mosquitos, snails, blooms of phytoplankton, other fish) and accidental (Welcomme, 1988; Coad, 1996; Cowx 1999; Innal, 2012).

The impacts associated with the introduction of alien fishes are many, including; competition, parasitism, predation, hybridization, alteration of habitat quality and/or ecosystem function and host of pests or parasites (Westman and Tuunainen, 1984; Copp et al., 2005; Roll et al., 2007; Britton et al., 2010; Pino Del Carpio et al., 2010; Innal, 2012).

The Turkish Rivers contain a distinctive fish fauna characterized by endemic species and species of biogeographic significance (Geldiay and Balik, 1999; Innal, 2012). Turkey's natural river systems have been anthropogenic altered in the past century and some alien fish species are now considered a threat factor for endemic species (Innal, 2012).

In present study, one of three specimens of an alien fish species which caught within 20 days by amateur fishermen in the Upper Kiz1lırmak Basin (Sivas city center) in July 2017 was examined. The morphological, metric and meristic characters of this specimen were determined based on the findings and species identification was made.

\section{Materials and Methods}

Three specimens of an alien fish species were caught by the amateur fishermen in July 2017 within 20 days in Kizılırmak River at Sivas city center. One of the fish specimens was consumed by the fishermen. Other one was thrown into the garbage. However, the last fish specimen was collected by the fishermen for ichthyologic examination. The morphological, metric (23 features) and meristic characters (13 features) of this specimen (female) were determined based on the findings and species identification was made. Also, electrofishing was carried out in the same area to determine density of alien fish in the river. For this aim, at two different sampling points were selected where the distance between them is about $3700 \mathrm{~m}$ in Kizılırmak River and fish sampling was repeated three times.

\section{Results and Discussion}

\section{Morphological Features}

The fish was characterized by ovoid shape and flattened laterally; mouth was in a sub-ventral position. The eye was large and snout was more or less rounded. The dorsal fin was in the middle position. There was an adipose fin behind the dorsal fin. The free margin of the anal fin was straight and caudal fin was slightly forked. The caudal peduncle was short and thick. The fish was small-scaled. Dorsally the body was dark-grey, the sides and ventral were silvery-white. The colour of dorsal and anal fins was black, however pectoral, pelvic and anal fins are orange or reddish (Figure 1). The teeth row was double and resemble to human teeth (Figure 2).

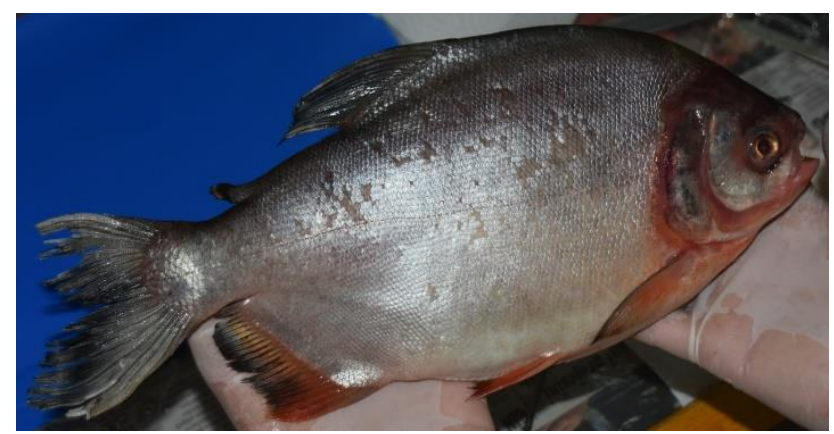

Figure 1. Alien fish sample collected from Kizılırmak River: total length $343 \mathrm{~mm}$.

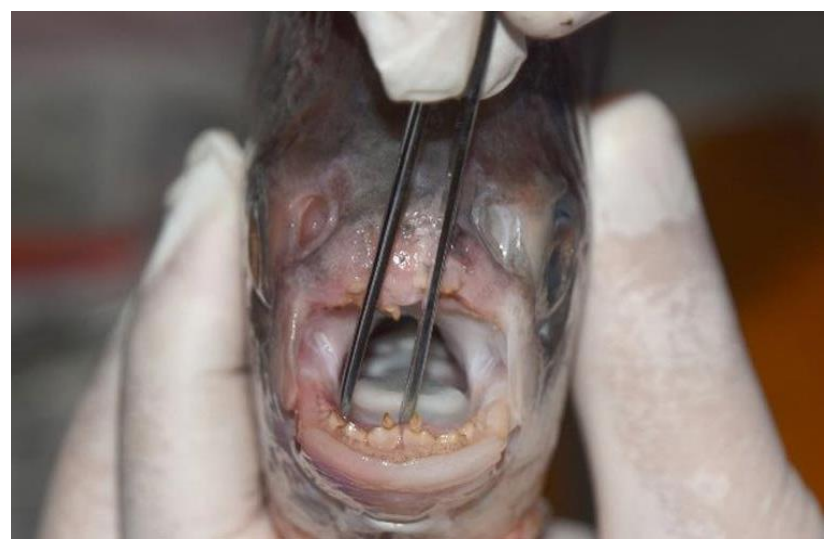

Figure 2. Alien fish sample showing the teeth of alien fish.

\section{Metric and Meristic Characters}

Descriptive data for the morphometric (23) and meristic (13) characters of alien fish specimen in Kizilırmak River is shown in Table 1 and Table 2; respectively. Total length of this specimen was $343 \mathrm{~mm}$ and teeth formula were 3,2 / 2,3 (at first row on maxil) and $2 / 2$ (at second row on maxil), 3,3 / 3,4 (at first row on mandibul), 1,1 (at second row on mandibul). The number of rakers on the first gill arch of alien fish was 33. The scale numbers in lateral line were 107 (on right side) and 103 (on left side). The number of branched rays of dorsal, anal, pectoral, and ventral fins were 14, 24, 14, and 7; respectively.

Based on the findings of the morphological, metric and meristic characters of alien fish specimen which were caught by the amateur fishermen within 20 days in Kizılırmak River at Sivas city center, it determined that this 
specimen is a species belonging to family Characidae. The scientific name of this species is Piaractus mesopotamicus (Holmberg, 1887). This species is called as the smallscaled pacu. This species is not among to native fish fauna of Kizılırmak. Pacu is a fish species which originated from South America including the Paraguay/Parana Rivers (Argentina, Bolivia, Brazil, Paraguay, and Uruguay) (Anonymus, 2019).

Table 1. Descriptive data of morphometric characters of alien fish sample collected from Kizılirmak River

\begin{tabular}{l|c}
\hline Characters & Values (mm) \\
\hline Total length & 343 \\
Fork length & 298 \\
Standart length & 261 \\
Max. body height & 132 \\
Body width & 46 \\
Head width & 42 \\
Head height & 71 \\
Orbit diameter & 17 \\
Preopercul distance & 19 \\
Predorsal distance & 140 \\
Preadipose distance & 230 \\
Postdorsal distance & 190 \\
Height of caudal peduncle & 31 \\
Length of dorsal base & 60 \\
Length of anal base & 72 \\
Length of pectoral base & 62 \\
Length of ventral base & 43 \\
Height of dorsal fin & 54 \\
Height of anal fin & 46 \\
Distance of pectoral-ventral & 71 \\
Distance of ventral-anal & 78 \\
Preanal distance & 190 \\
Postadipose distance & 31 \\
\hline
\end{tabular}

Table 2. Descriptive data of meristic characters of alien fish sample collected from Kizılirmak River

\begin{tabular}{l|c}
\hline Characters & Values \\
\hline Rays of dorsal fin & III / 14 \\
Rays of anal fin & IV / 24 \\
Rays of pectoral fin & I / 14-15 \\
Rays of ventral fin & I / 7 \\
Lateral line (right) & 107 \\
Lateral line (left) & 103 \\
Transversal line & 32 / 33 \\
Rays of caudal fin & IV / 20 \\
Teeth row (maxil-1 st. row) & 3,2 / 2,3 \\
Teeth row (maxil-2 nd. row) & 2 / 2 \\
Teeth row (mandibul-1 st. row) & $3,3 / 3,4$ \\
Teeth row (mandibul-2 nd. row) & $1 / 1$ \\
Gill rakers & 35 \\
\hline
\end{tabular}

$P$. mesopotamicus which is not among to native fish fauna of Kizilırmak River, but caught by amateur fishermen probably translocated from a hobbyist aquarium to this aquatic system. In the last decade, similar translocate events of the aquarium species have been identified in the various aquatic systems in Turkey (Eğirdir Lake; Isparta-2002, Sapanca Lake; Adapazar1-2009, Meriç River; Edirne-2012, İznik Lake; Bursa-2013 and 2015, Altınapa Dam Lake; Konya-2016, Seyhan Dam Lake;
Adana-2016, Yeşilırmak; Amasya-2016). Nico and Loftus (2018) attribute introductions of $P$. mesopotamicus in the United States to the aquarium trade pathway. Gozlan (2008) stated that, the ornamental aquarium trade, along with the stocking for angling and aquaculture, is one of the most important pathways of freshwater fish introduction. By nature, people are the main vector of freshwater fish movements across river basins or countries. The general understanding is that freshwater aquaculture production is increasing (FAO sources) and is a major driver of freshwater fish introductions. The overall number of fish species introduced worldwide from known sources reaches 624 species from which $91 \%$ is explained by a need of fish for food $(51 \%)$, hobbyist fish $(21 \%)$, angling or sport $(12 \%)$ or fisheries (7\%) (Gozlan, 2008).

One of the most insidious threats to fish conservation around the world is deliberate or accidental introduction of fish species (Cambray, 2003). Certain freshwater fish species used for recreational angling have been transported around the globe to rivers, dams and lakes, frequently without environmental impact assessments or monitoring (Innal, 2012). The impact of alien invasive sport fish is for the most part unpredictable in time and space, with the introduction of relatively few species having resulted in many extirpations of indigenous fish species worldwide (Cambray, 2003). The introduction of alien fishes is a major cause of biodiversity decline in freshwater ecosystems (Rowe et al., 2008; Innal, 2012).

A total of 25 exotic species have been introduced as eggs, fry or fingerlings for different purposes over the last five decades. Some of these fish have been used only in closed systems while others have been released into open inland waters throughout the country. Fourteen native species and members of two genus (Mugil and Liza) have also been translocated from their original systems to habitats elsewhere in Turkey. Gambusia sp. is possibly one of the earliest deliberate exotic introductions although there are no exact records (Innal and Erk'akan, 2006).

Biological invasions are numerous in fresh waters around the world. At least hundreds of freshwater species have been moved outside of their native ranges by vectors such as ballast water, canals, deliberate introductions, and releases from aquaria, gardens, and bait buckets. As a result, many bodies of fresh water now contain dozens of alien species. Invasions are highly nonrandom with respect to the taxonomic identity and biological traits of the invaders. The ecological characteristics of the ecosystems that are invaded, and the geographical location of the ecosystems that supply and receive the invaders (Gozlan, 2008; Strayer, 2010). Both directly and indirectly, invasive fishes affect a wide range of native organisms from zooplankton to mammals across multiple levels of biological organizations ranging from the genome to the ecosystem (Cucherousset and Olden, 2011). The costs of preventing and controlling invasive species are not well understood or documented, but estimates indicate that the costs are quite high, in the range of millions to billions of dollars per year (Lovell and Stone, 2005. For the U.S., the environmental losses from introduced fish are estimated at US\$1 billion a year (Pimentel et al., 2000; Pimentel et al., 2001; Lovell and Stone, 2005).

Until now, several alien fish species have been identified in some parts of the Kizllirmak River Basin: 
Pseudorasbora parva (Hirfanl1 Dam Lake), Oncorhynchus mykiss (Kesikköprü Dam Lake) (Innal, 2012). However, no scientific record has been made about any alien fish species for Sivas aquatic systems. Therefore, the presented study is the first scientific study for Sivas aquatic systems in Upper Kizılırmak Basin.

\section{Fish Sampling Activities}

To determine density of alien fish in the river, electrofishing was carried out in the study area. For this aim, two different sampling points were sampled where the distance between them is about $3700 \mathrm{~m}$ in Kizılırmak River and fish sampling was repeated three times. As a result of sampling, no alien fish was found except samples of native fish fauna of the region (Figure 3). These alien fish specimens which are caught by amateur fishermen probably were translocated from a hobbyist aquarium to this aquatic system. $P$. mesopotamicus is a tropical freshwater fish. It tolerates water temperatures between 15 and $35^{\circ} \mathrm{C}$ and $\mathrm{pH}$ between 5.0-7.8, but stops feeding when it falls below $18{ }^{\circ} \mathrm{C}$. Pacu is omnivore characteristics; young individuals usually feed on micro-crustaceans, while adults feed on plant material and insects. Main food items for adults are nuts and seeds that fall from trees in flooded forests. The most important food item in the pacu diet is fruit of the palm (Nico and Loftus, 2018; Anonymous, 2019; Agostinho et al., 2021). Accordingly, the limnological features of Kizılırmak River are not suitable for survive and reproduce of pacu ( $P$. mesopotamicus) in this aquatic system.

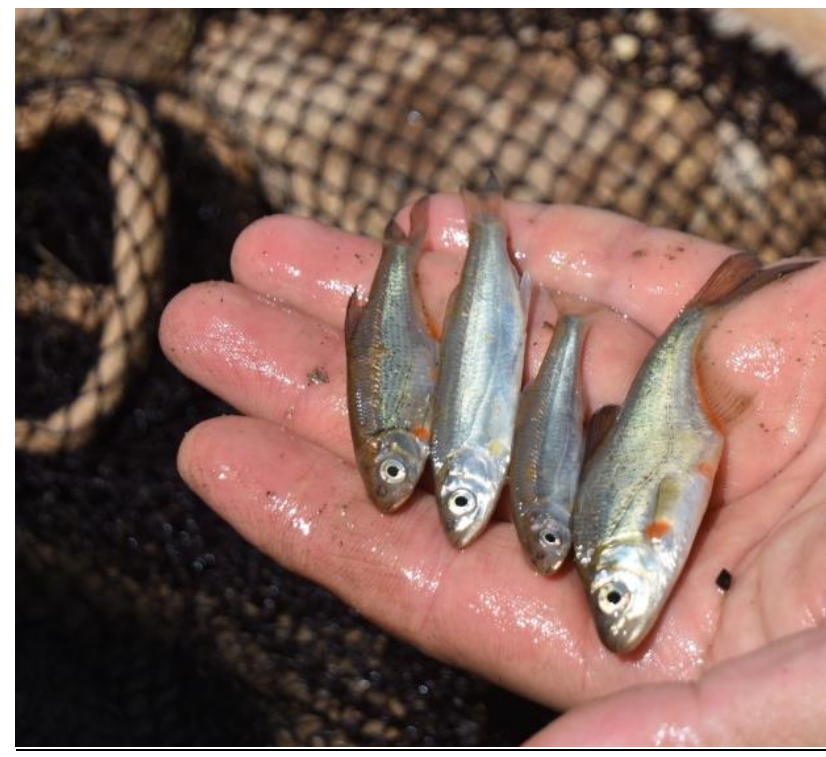

Figure 3. Samples of fish fauna from Kizilırmak River (sampling area).

New Mexico Department of Game and Fish (2010) stated that, all piranha and pacu (Family: Characidae) are listed in Group IV. Species importation list group IV may be for live non-domesticated animals that are considered dangerous, invasive, undesirable, state or federal listed threatened, endangered, a furbearer or any other species of concern as identified by the director. The importation of these species are prohibited for the general public but may be allowed for, scientific study, department approved restoration and recovery plans, zoological display, temporary events/entertainment, use as service animal or by a qualified expert (Anonymous, 2010). It is recommended to ban the ornamental aquarium trade of piranha and pacu species in Turkey, except for scientific studies. In order to avoid similar fish introductions in Kizilırmak River, it is necessary to control of activities of hobbyist aquarium more carefully. It should be ensured that people's awareness about the possible adverse effects of alien species and fish translocation on aquatic ecosystems and biodiversity is increased (Anonymous, 2019).

Although a great deal of information has been obtained recently on alien and invasive fish species, this mass of information is still insufficient compared to what we need to learn. In particular, it is thought that new scientific research is required to overcome the lack of knowledge mainly caused by biological, ecological, disciplined and methodologically unstable aquaculture activities (Cucherousset and Olden, 2011).

\section{Conclusion}

Biological invasions are numerous in fresh waters around the world. The impacts associated with the introduction of alien fishes are many, including; competition, parasitism, predation, hybridization, alteration of habitat quality and/or ecosystem function and host of pests or parasites. It is known that the introduction of alien fishes is a major cause of biodiversity decline in freshwater ecosystems. Exotic and translocated fish species have become established in various parts of the inland waters of Turkey since the 1950s. The presented study is the first scientific record for Sivas aquatic systems related to alien fish species in Upper Kızılırmak Basin.

\section{References}

Agostinho AA, Gomes LC, Suzuki HI, Ferreira Júlio H. 2021. Migratory fishes of the Upper Paraná River basin, Brazil. Available from: https://en.wikipedia.org/ [Accessed 9 February 2021].

Anonymus 2010. New Mexico Department of Game and Fish. Director's species importation list. Available from: http://www.wildlife.state.nm.us/ [Accessed 8 March 2021].

Anonymus 2016. Convention on Biological Diversity. United Nations, 13 pp., EFSA. Available from: http://www.efsa.europa.eu/ [Accessed 8 March 2021].

Anonymus 2019. Small-scaled Pacu (Piaractus mesopotamicus) Ecological Risk Screening Summary. U.S. Fish and Wildlife Service, 1-13. Available from: https://www.fws.gov/fisheries/ [Accessed 13 February 2021].

Britton JR, Gozlan RE, Copp Gordon H. 2010. Managing nonnative fish in the environment. Fish and Fisheries, 12 (3): 256-274.

Cambray JA. 2003. Impact on indigenous species biodiversity caused by the globalisation of alien recreational freshwater fisheries. Hydrobiologia. 500: 217-230. Available from: https://link.springer.com/ [Accessed 9 February 2021].

Coad BW. 1996. Exotic and transplanted fishes in southwest Asia. Publicaciones Especiales Instituto Espanol de Oceanografia. 21: 81-106.

Copp GH, Garthwaite R, Gozlan RE. 2005. Risk identification and assessment of non-native freshwater fishes: Concepts and Perspectives on Protocols for the UK, Cefas Science Series Technical Report No.129. 
Cowx IG. 1998. Stocking and introduction of fish. Fishing News Books, Blackwell Science, Oxford.

Cowx IG. 1999. An appraisal of stocking strategies in the light of developing country constraints. Fisheries Management and Ecology. 6: 21-34.

Cucherousset J, Olden JD. 2011. Ecological Impacts of Nonnative Freshwater Fishes. Fisheries. 36 (5): 215-230. Available from: https://moam.info/ [Accessed 13 February 2021]

Geldiay R, Balık S. 1999. Türkiye Tatlısu Balıkları. Ege Üniversitesi Su Ürünleri Fakültesi Yayınları, İzmir.

Genovesi P, Carnevali L, Scalera R. 2015. The impact of invasive alien species on native threatened species in Europe. Available from: http://www.biodiversity.de/ [Accessed 4 February 2021].

Gozlan RE. 2008. Introduction of non-native freshwater fish: is it all bad? Fish and Fisheries. 9: 106-115. Available from: https://onlinelibrary.wiley.com/ [Accessed 14 February 2021].

Heubach K. 2016. Of global concern: Invasive Alien Species. Network-Forum for Biodiversity Research Germany (NEFO). Available from: http://docplayer.net/ [Accessed 13 February 2021].

Innal D, Erkakan F. 2006. Effects of exotic and translocated fish species in the inland waters of Turkey. Rev. Fish Biol. Fisheries. 16: 39-50.

Innal D. 2012. Alien fish species in reservoir systems in Turkey: a review. Management of Biological Invasions. 3 (2): 115119. Available from: https://www.reabic.net/ [Accessed 19 February 2021].

Lovell SJ, Stone SF. 2005. The economic impacts of aquatic invasive species: A review of the literature. U.S Environmental Protection Agency, Washington. Available from: https://www.epa.gov/environmental-economics [Accessed 4 March 2021].
Nico L, Loftus B. 2018. Piaractus mesopotamicus (Holmberg, 1887): U.S. Geological Survey, Nonindigenous Aquatic Species Database, Gainesville.

Pimentel D, Lach L, Zuniga R, Morrison D. 2000. Environmental and economic costs of non-indigenous species in the United States. Bioscience. 50 (1): 53-65.

Pimentel D, McNair S, Janecka S, Wightman J, Simmonds C, O'Connell C, Wong E, Russel L, Zern J, Aquino T, Tsomondo T. 2001. Economic and environmental threats of alien plant, animal and microbe invasions. Agriculture, Ecosystems and Environment. 84: 1-20.

Pino Del Carpio A, Miranda R, Puig J. 2010. Non-native freshwater fish management in biosphere reserves. Management of Biological Invasions. 1: 13-33.

Roll U, Dayan T, Simberloff D, Goren M. 2007. Characteristics of the introduced fish fauna of Israel. Biological Invasions. 9: 813-824.

Rowe DK, Moore A, Giorgetti A, Maclean C, Grace P, Wadhwa S, Cooke J. 2008. Review of the impacts of gambusia, redfin perch, tench, roach, yellowfin goby and streaked goby in Australia. Prepared for the Australian Government Department of the Environment, Water, Heritage and the Arts.

Strayer DL. 2010. Alien species in fresh waters: ecological effects, interactions with other stressors, and prospects for the future. Freshwater Biology. 55 (Suppl. 1): 152-174.

Welcomme RL. 1988. International Introductions of Inland Aquatic Species, FAO Fisheries Technical Paper 294.

Westman K, Tuunainen P. 1984. A review of fish and crayfish introductions made in Finland, stock enhancement in the management of freshwater fish. EIFAC, Technical Paper. 42 (Suppl. 2): 436-447. 